It is certainly very far from my desire to discourage the present attempts which are being made to clear the atmosphere of our large towns of smoke, and I have recognised the advantages which wculd result from the adoption of more perfect forms of combustion. In my paper I have simply distinguished between fogs and smoke, and separated them for distinct consideration and treatment, and have at the same time directed attention to some points which ought to be consiclered before deciding on their prevention.

With regard to Mr. Russell's difficulty in reconciling the result of the experiments with what is observed with regard to fogs in London, Paris, and other large towns, it appears to me to have arisen entirely from not putting sufficient weight on the allimportant influence of the amount of vapour in the air of the different places. It is condensed vapour which forms the fog, and dust simply determines whether it will condense in fine- or coarse-grained particles. The atmosphere of Paris, compared with that of London, is an extremely dry one, and the air is seldom in a condition to produce fogs. The atmospheres of the other towns mentioned are also drier, some of them very much drier, than that of London. London however will probably be always more subject to fogs than other cities on account of its great size, some part of it being always in its own smoke.

Considered from a different point of view, might not the fog of January $3 \mathrm{I}, \mathrm{I} 88 \mathrm{o}$, referred to by your correspondent, be cited in evidence of a conclusion the opposite of that drawn by the writer, and in favour of the correctness of the experimental results? From this point of view the low white fog cleared away because it was formed in the comparatively pure air of the streets, while the higher fog did not clear away because it was formed in the products of combustion The true explanation however would rather appear to be, that where the fog was white it was also of less depth than in those places where it "extended high" and mixed with the smoke ; and the sun, which was only sufficient to dispel the lesser depth "more or less," would evidently be insufficient to clear away the greater depth. It is however impossible to form any definite idea as to how this par ticular fog conducted itself, without much fuller information as to air-current, \&c.

I have communicated to the secretary of the Royal Society of Edinburgh a second experimental paper on fogs, with special reference to dry fogs. In this paper the full answer to the latter part of Mr. Russell's letter will be found. JoHN AitKen

Darroch, Falkirk, January 24

\section{Professors Exner and Young}

My statement in respect to Prof. Exner's having announced the thermo-electric neutrality of a bismuth-antimony pair immersed in pure nitrogen, rested upon a note in NATURE (vol, xxii. p. I 56), and this it seems was based upon a statement in L'Electricité. I have seen those of Prof. Exner's papers which have appeared in the Annalen der Physik, and there is certainly nothing of the sort in them; but I supposed that it must be contained in some other paper in some one of the numerous other publications to which I have not access here. It never occurred to me, until within a very short time, that there could be any mistake as to his having made such an assertion. How or where the error originated I cannot quite understand; but I trust Prof. Exner will accept my apologies for my share in its propagation, and that he and all concerned will be satisfied that no misrepresentation was intended on my part. The incident is a good illustration of the extreme care necessary in commenting upon the views of another person. $\quad$ C. A. YounG

Princeton, U.S.A., January 12

\section{The Flying-fish}

IT is remarkable that there should still be any doubt as to the facts in connection with the flight of the flying-fish. Dr. Günther ("Study of Fishes," p. 622), summarising the observation of Möbius, says that "they frequently overtop each wave, being carried over it by the pressure of the disturbed air" (in the open sea!). Again, flying-fishes "never" fall on board vessels "during a calm or from the lee side." At night "when they are unable to see they frequently fly against the weatherboard, when they are caught by the current of air and carried upwards to a height of twenty feet above the surface of the water." Surely the fish going at the rate of at least ten miles an hour would on striking the "weather-board" be dashed, bruised and helpless, back into the water instead of coming over the side fresh and vigorous, flapping about on the deck. Except when "by a stroke of its tail" it turns towards the right or left, Möbius concludes that "any deflection from a straight course is due to external circumstances, and not to voluntary action on the part of the fish."

I have watched flying-fish repeatedly, and have invariably seen them fly, or rather glide, over the surface of the sea, and from one to two feet above it, rising gently to the swell when there was no wind, and occasionally turning to the right or left without touching the water. I do not say that when there is a breeze the tail of the fish may not touch it, but I think that, with the foam and spray of the broken water, it would be very difficult to be sure of it, and, moreover, if the tail was used the motion would be a jerking one. Mr. Wallace speaks of their "rising and falling in the most graceful manner," which, although he is referring to another species, applies also to the North Atlantic form (Exocatus evolans). Mr. Bennett ("Gatherings," \&c., p. I4) says that they "spring from the sea to a great elevation." This is probably in reference to their coming on board ship at night, attracted, it is supposed, by the lights. I believe the pectoral fins are kept extended without any motion, except perhaps as Mr. Whitman, ${ }^{1}$ a recent observer, says, just when they rise from the sea. He gives 800 to 1200 feet as the greatest distance he has seen them fly, and about forty seconds as the longest time out of the water. By what mechanical means they move when out of the water is still to me a mystery.

I have never known the flying-fish to be pursued by other fish, nor ever seen any bird near them; indeed few birds are ever seen far from the land north of the southern tropic, where flying. fish are most abundant. The dolphin (Coryphana) is supposed to be their greatest enemy. I had once an opportunity of seeing one opened-in the West Indies-its stomach was quite full of Orthagoriscus mola, very young, being not quite an inch long.

I, Burlington Road, W., January 2I

FRANCIS P. PASCOE

\section{Mr. S. Butler's "Unconscious Memory"}

I MUST reply to the review of my book, "Unconscious Memory," in your issue of the 27 th inst., and to Dr. Krause's letter on the same subject in the same issue.

Mr. Romanes accuses me of having made "a vile and abusive attack upon the personal character of a man in the position of Mr. Darwin," which I suppose is Mr. Romanes' way of saying that I have made a vile and abusive personal attack on $\mathrm{Mr}$. Darwin himself. It is true I have attacked Mr. Darwin, but $\mathrm{Mr}$. Romanes has done nothing to show that I was not warranted iu doing so. I said that Mr. Darwin's most important predecessors as writers upon evolution were Buffon, Dr. Erasmus Darwin, Lamarck, and the author of the "Vestiges of Creation." In the first edition of the "Origin of Species" Mr. Darwin did not allude to Buffon nor to Dr. Erasmus Darwin, he hardly mentioned Lamarck, and he ignored the author of the "Vestiges" except in one sentence. This sentence was so gross a misrepresentation that it was expunged-silently - in later editions. Mr. Romanes does not and cannot deny any part of this.

I said Mr. Darwin tacitly claimed to be the originator of the theory of evolution, which he so mixed up with the theory of "Natural Selection" as to mislead his readers. Mr. Romanes will not gainsay this. Here is the opening sentence of the "Origin of Species":-

"When on board H.M.S. Beagle as naturalist, I was much struck with certain facts in the distribution of the inhabitants of South America, and in the geological relations of the present to the past inhabitants of that continent. These facts, as will be seen in the latter chapters of this volume, seemed to throw some light on the origin of species; that mystery of mysteries, as it has been termed by one of our greatest philosophers. On my return home it occurred to me in 1837 that something might perhaps be made out on this question by patiently accumulating and reflecting upon all sorts of facts which could possibly have any bearing on it. After five years' work I allowed myself to speculate upon the subject, and drew up some short notes; these I enlarged in 1844 into a sketch of the conclusions which then seemed to me probable; from that period to the present day I have steadily pursued the same object. I hope that I may be I See Zoologist for November, 1880 . 